Marquette University

e-Publications@Marquette

$3-1-2008$

Distributive Justice: Pressing Questions, Emerging Directions, and the Promise of Rawlsian Analysis

Gene R. Laczniak

Marquette University, eugene.laczniak@marquette.edu

Patrick Murphy

University of Notre Dame

Accepted version. Journal of Macromarketing, Vol. 28, No. 1 (March 2008): 5-11. DOI. (C) 2008 SAGE Publications. Used with permission. 


\section{Distributive Justice: Pressing Questions, Emerging Directions, and the Promise of Rawlsian Analysis}

Authors: Gene R. Laczniak \& Patrick E. Murphy

Over the years, the concept of distributive justice (DJ) has consistently been defined as addressing how a community treats its members in terms of the assignments of benefits and burdens according to some standard of fairness (Johnson 1956; Jackson 2005). Unlike other aggregate concepts used in social economics and macromarketing (e.g., Quality of Life or living wage) that have dynamically shifted definitions depending on time and place, our understanding of the core meaning of DJ has remained remarkably stable. Despite the definitional stability, as we learn below, this situation does not mean that arriving at a consensus about whether DJ has been attained in specific business situations is simplistic or uncontroversial. Indeed, as we shall see, quite the opposite seems to be the case.

From our initial definition above, it follows that DJ applied to marketing deals with how the marketing system, in terms of its structure, policies, or practices, fairly apportions rewards and penalties among the various parties affected by the market exchange process. Examples of topical issues with DJ implications that come to mind are: (1) the treatment of suppliers and consumers when marketers establish footholds in emerging markets, (2) the seeming lack of leverage for subprime borrowers when they try to purchase a home or automobile, and (3) the proportionate awards going to migrant farm workers who are employed in the agribusiness supply chain. As globalization of the economy inevitably expands further and business targets more impoverished market segments, the concerns of DJ will only become more critical.

Of course, no definition of a particular social concept exists in a vacuum. A further consideration in any analysis of $\mathrm{DJ}$ in a marketing context is that it is tethered in clear connection to major streams of the marketing literature, especially ethics, public policy, and macromarketing. Together these research connections create a "distributive justice nexus" worth noting because these highlighted areas of the marketing literature can shed insight on DJ questions. This nexus is summarized in Figure 1 and is now discussed briefly.

\section{The DJ Nexus}

DJ has an ethics component because it concerns the fairness of allocations; such adjudications always involve inherently moral judgments (Laczniak 1999). In fact, the American 
Marketing Association Statement of Norms and Values lists fairness as one of six ethical values for marketers. For example, even when the transactions between a large retailer and consumers are overwhelmingly positive and satisfying, members of the supply chain may have been unfairly exploited as a by-product of that system. For instance, some have claimed-perhaps too stridently—that while "big box" retailers are advantageous for large numbers of consumers, some of these benefits have come at the disproportionate expense of small suppliers and family-owned retail competitors (Fishman 2003). While big box retailing is clearly a net economic plus, this occurrence may have happened due to a flaw in the distributional system that did not fairly compensate all the players in the value chain. Such DJ questions are germane to the moral responsibility of marketing. In articulating what they consider to be the major normative perspectives of ethical marketing, Laczniak and Murphy (2006) portray the principle of DJ as one of the fundamental ethical tenets to be considered when evaluating the social dimensions of marketing practices.

DJ also has a public policy component because inequities (i.e., benefits and burdens) resulting from "unfair" marketing practices are often remedied by legal regulation (Gundlach, Block, and Wilkie 2007; Gundlach and Murphy 1993). The Federal Trade Commission adopted the fairness doctrine some years ago to promote more ethical advertising. For instance, while marketers have the right to gather information from consenting parties via the Internet, their ability is markedly restricted when it comes to gathering information from minors owing to the Children's On-line Privacy Protection Act (COPPA) of 1998. Day and Montgomery (1999), writing about challenges facing the field of marketing in the twenty-first century, urge increased academic research into the secondary effects of marketing practices particularly so that such investigations might inform public policy adjustments necessary for sectors of marketing.

Finally, DJ has a distinctly macromarketing flavor because it is often the extant marketing system (or subsystem) that consistently skews outcomes toward an unfair result for certain parties. For example, if legal transactions involving particular products regularly create "externalities" that must be borne by the public at large, and public policy seems to be an unlikely remedy, systemic issues might be at root. The resource consumption and safety-to-others issues associated with oversized SUVs or the savings disincentives and human addictions attributed to the gambling industry are possible illustrations of such unaccounted for dysfunctions that are unlikely to be fixed through near-term regulation. Such issues can raise questions about the design of the exchange system itself.

Layton and Grossbart (2006) recently took stock of the rich history of macromarketing research, including the writings that specifically address DJ. They conclude that "[these]

\section{Laczniak \& Murphy}


challenges are grounded in macromarketing's intellectual and normative traditions. . . They deal with the interaction of marketing and society and the workings of marketing systems at different levels of aggregation" (p. 208). Issues such as the systemic roots of the overconsumption of resources, Quality-of-Life outcomes and at-risk consumer segments are prominent in these discussions. In a similar vein, Mittelstaedt, Kilbourne, and Mittelstaedt (2006) opine that certain marketing externalities cannot be understood without reference to the systemic agora. Thus, in addition to law and ethics, the nature of marketing systems and subsystems requires periodic analysis. Wilkie and Moore (2003), evaluating the evolution of marketing thought, observe that previously robust macromarketing thinking has been relatively deemphasized in the overall marketing literature in recent years and needs to be revived. In a follow-up commentary on this topic (2006), they further write:

Macromarketing is involved in comprehending, explaining and predicting the effects that the marketing system can have, and is having, on our world. This should certainly be a central concern for marketing scholarship. (p. 231)

In the Call for Papers that motivated this special issue of the Journal of Macromarketing, the editors sought to stimulate research and analysis that address the fundamental components circumscribing the realm of DJ as applied to broader marketing concerns. Basically, we encouraged academic researchers to examine the ethical dimensions of the market system and subsystems, especially those prevalent marketing practices that raise questions about the fairness of how the benefits and burdens of exchange decisions are apportioned among various stakeholders. These emphasized terms might be seen as the basic elements endemic to discussions about DJ in marketing.

The first two elements—ethical dimensions and questions of fairness—have already been introduced. However, it is also important to note that the involvement of ethics implies that DJ often addresses issues that are not yet regulated by law. For example, due to the burgeoning Internet and its robust databases, the relative bargaining power of buyers and sellers in certain market settings has changed dramatically. In some cases (e.g., buying an automobile in the United States), the information available about the transaction has substantially improved for the buyer (Urban 2005). In many other situations, the leverage of sellers has rapidly been enhanced due to their knowledge of individual buyers (e.g., loan applications and gaming patterns at casinos; Grow and Epstein 2007). Some of these microsystems (e.g., the bundling of high-risk mortgage loans as financial instruments) may require additional future regulation to assure a more balanced fairness in the exchange-at least when this is perceived to be necessary by the general public.

\section{Laczniak \& Murphy}


The focus on benefits and burdens of exchange, at first glance, suggests a teleological preoccupation with outcomes. And while outcomes are central to a discussion of DJ, this is not a purely utilitarian exercise since the assurance of fairness may require that certain deontological rules also need to be applied. In terms of the implicit social contract between marketing and the community, DJ has regularly addressed policies (i.e., customized rules) for the protection of vulnerable populations (Baker, Gentry, and Rittenburg 2005). In a marketing context, this raises the question of special covenants owing to vulnerable populations of every stripe-refugees, immigrants, the elderly, market illiterates, the addicted, and minors (e.g., Shultz et al. 2005; Hill and Adrangi 1999; Adkins and Ozanne 2005; Murphy et al. 2005). Given the Millennial Goals of the United Nations and other affiliated international agencies and nongovernmental organizations (NGOs) for world poverty reduction, marketer obligations to impoverished consumers, especially in developing countries, have become a prominent social imperative (Kotler, Roberto, and Leisner 2006).

The element of DJ that centers on the impact of marketing processes of all affected parties evokes the notion of stakeholders. Stakeholders include all persons and organizations impacted by a given marketing action or policy. Such concerns are central to marketing practice, and this term is explicitly included in the formal definition of marketing as promulgated by the American Marketing Association (2004). That definition specifies, in part, that marketing is about "managing customer relationships" and "creating, communicating and delivering value to customers" for their benefit and for that of other stakeholders. Focus on benefits clearly implies asking whether consumers are receiving their fair desserts from the marketing transaction. But the mention of stakeholders further suggests evaluating other parties affected by marketing. For example, does a marketing system that allows easy access to handguns (including a vast majority of buyers and sellers who are satisfied with their transactions) create a quality of life in the community that is truly better for all concerned (Gundlach, Wilkie, and Bradford 2007)? Such a question is surely within the realm of DJ, but the nub of this issue involves determining how much weight (and voice) should be given by the seller to stakeholders that might not be considered primary (e.g., members of the general public who are not buyers or consumers of handguns, but live in a more dangerous community because of these exchanges).

\section{But Really, What is Fair?}

One of the overarching issues with regard to DJ is the question, What is fair? Or, put another way, Whose conception of fairness should be utilized to settle competing marketing claims? Different parties will have alternative perceptions about the rights that accrue to various 
customers and other stakeholders as a result of marketing transactions. For example, in the contemporary marketplace, the bromide that "the customer is always right" is being increasingly challenged by sellers. According to a National Public Radio report (July 13, 2007), Sprint strongly invited (by letter) 1,000 subscribers who had "too frequently" used its customer service line to find another vendor for cellular telephone services. Presumably, the cost of servicing their ongoing questions and complaints exceeded their future value as paying customers.

Concerning DJ, some might argue that any specified decision-making system, publicized in advance to all relevant parties, which deals with outcomes in a consistent manner is just. In other words, if you are told the rules of the game, and then if they are evenhandedly applied, fairness exists—by definition. Theoretical possibilities might include: (1) outcomes should be equal for all, (2) rewards should be divided based upon effort expended, and (3) awards should be divvied up according to merit. Obviously, different rules of apportionment will lead to dramatically different outcomes. Still another more pragmatic rule, at least in the opinion of many, would be that the "invisible hand" of the marketplace should decide economic outcomes subject only to applicable legal regulation. The idea behind this last scheme is the supposition that there is no judge more impartial (or blindly just) than the unfettered workings of the economic marketplace. The difficulty with any of these approaches, at least in the abstract, is that they lack an ethical rationale. As argued above, it appears that DJ as fairness has an inherent moral component and, thus, ought to be subject to prudent and thoughtful ethical justification.

\section{Rawlsian DJ and Marketing}

Allowing that DJ has an ethical component (recall the first element), one can reasonably argue that just outcomes need to be evaluated based upon ethical rules (Santos and Laczniak 2006). One of the first places that such a quest for ethical moorings would lead us is to the monumental writings of the late John Rawls and, in particular, his Theory of Justice (1971). Rawls focuses on Justice as his central moral platform because he conceives of it as the fountainhead civic virtue - the one that must be present to secure all other rights and liberties that are essential-freedom of speech, the right to assembly, property rights, religious freedom, and all the other basic liberties that most democracies consider to be inalienable. Using a thought experiment referred to as "the original position," Rawls contends that if individuals did not know in advance their station in society (i.e., wealth, power, personal abilities, place of residence, health, gender, etc.), they would, under this "veil of ignorance," rationally develop supreme guidelines that differ markedly from those that govern many current social, civic, and economic situations. In particular, by constructing a detailed articulation of rational choice, one not unlike the

\section{Laczniak \& Murphy}


development of the "rational economic man" theory, Rawls further postulates that reasoning people would inevitably wish to avoid catastrophic outcomes for themselves (i.e., because they would not know in advance about their "revealed" position in the "new" world after the previously imposed veil of ignorance has been removed). Thus, impartial rational beings would craft a social system that would allow them a built-in social impetus to recover from uncontrollable personal and financial setbacks of various kinds. Rawls then proposes that from this original position, rational persons would choose to be "minimaxers" with regard to their social status and social risk (i.e., they would want to avoid the direst of outcomes and would be willing to forego some upside potential to achieve that). As a result of this process, rational thinkers in the original position would ultimately arrive at two supreme moral principles:

- The liberty principle (LP) states that each person is to have equal right to the most extensive basic liberty compatible with a similar liberty for others.

- The difference principle (DP) includes the central idea that social policies are to be evaluated so that any inequalities are arranged to be to the benefit of the least well-off.

The first principle, the LP, is very consistent with the individualism of the American political system and its liberal economic tradition. Freedoms should be maximized as long as the rights of others are not violated. The second principle (the DP) is a bit more complex and debatable. As we wrote in 1993 concerning the implications of the DP,

The difference principle ... states that actions should not be taken that will further disadvantage those groups in society that are least well off. In other words, corporate actions should be formulated in such a way that the social and economic inequalities are arranged so that the greatest benefit accrues to the least advantaged. The principle - a somewhat controversial one-is basically an affirmative action principle for the poor and politically underrepresented groups in society.

Over time, it should make those "least well-off, better off" because public policy will be formulated to empower most those who are at the bottom of the social and economic pyramid (Laczniak and Murphy 1993). In effect, with these two perspectives in place, Rawls creates the fundamental backbone of an ethical system for judging the fairness of outcomes as systemic distributions occur. Some critics have characterized Rawlsian justice as neo-communistic, but this seems a misreading since inequalities are allowed as long as they are to the benefit of everyone. For example, logistical engineers that create an innovative supply chain whose efficiency benefits everyone deserve opulent rewards. While it seems obvious that many will still disagree with 
Rawlsian justice due to its communitarian tendencies, it deserves consideration as marketers ponder questions of DJ since, as we have stressed above, judgments about "fairness" ought to be anchored in moral theory as opposed to idiosyncratic rules, perceptions, or randomness.

Some of the other major criticisms and weaknesses of Rawls's formulations should be noted for the record (Velasquez 2006). Critics find the original position used to arrive at the supreme principles to be an exercise that undercuts the reality of the current situation in society. These doubters of Rawls contend that inequalities are rife in existing systems and that he offers an ideal so pure as to be practically unrealistic and unattainable. It certainly is true that the veil of ignorance is an abstract, intellectual exercise that belies the inequalities of the current state of affairs. But it also addresses a form of the naturalistic fallacy present in many philosophical discussions wherein some persons mistakenly presume that because something commonly exists in nature, that makes it morally acceptable.

In yet another criticism of Rawls, some skeptics reject the claim that rational persons would attempt to protect themselves from major, negative outcomes. These critics would contend that gambling and risk-taking are basic to human nature and that Rawls's conception of a risk-averse rational man is deeply flawed. "Who is to say what is rational?" these critics assert. (As an aside, it might be observed that analogous criticisms might be made about the rational economic man central to the Marshallian economics at the core of the capitalistic system.)

Finally, the keystone DP is also without sufficient detail in the opinion of many. Who exactly are those least well-off who must be catered to? Is it the bottom 10 percent? Is it the bottom quintile? And to what social elements does disadvantage apply? Does social disadvantage include only the impoverished, or are factors such as the lack of access to basic health care and higher education also to be included? Rawls himself later noted that the DP was designed with a North American, Western European context in mind, and it might not be conveniently applicable to the development of the third world, given its prohibitively costly economic implications owing to widespread poverty.

The point in articulating the thinking of Rawls is not to endorse his approach as the only valid one for conceptualizing $\mathrm{DJ}$ in a marketing context. Indeed, one purpose of this special issue is to stimulate creative thought about new or hybrid approaches for addressing about the fairness problem inherent in certain classes of marketing transactions and market subsystems. But that said, Rawls does offer an ethical rationale that speaks to the increasingly common vulnerable consumer segment debate that is emergent in recent CSR discussions (Rangan and McCaffrey 2004). Creative applications of Rawls and related approaches may be especially useful as billions of new consumers, most of them impoverished in various ways, enter the system for expanded

\section{Laczniak \& Murphy}


marketing offerings in a globalized world (Prahalad 2005).

\section{DJ and Macromarketing Analysis: The Special Issue}

With tough issues in mind comparable to those alluded to already, the authors whose work appears in this special issue of the Journal of Macromarketing address various questions of fairness, equity, and justice attributable to the roles of the sundry participants in the marketing system. There is no question that when one confronts the realm of DJ, the discussions are complex, messy, and emotionally charged. Evaluated in this special issue of the Journal of Macromarketing are various problems that require adjudicating the thorny tradeoffs inherent within these debatable marketing situations. Collectively, it is our judgment that these articles make clear and notable progress in helping fellow researchers comprehend many of the key variables that must be assessed to answer the perennial and overarching question of DJ: Is this a fair and just marketing practice? The articles included in this special issue address the theories of DJ, the methodologies inherent in creating justifiable market apportionments, several intricacies of common and salient marketing practices that directly attempt to create fairer exchange in the macromarketing system, and new considerations (i.e., corrective justice) for redressing what might be considered to be unjust situations in a marketing context.

In their article, "A Theory of the Firm Perspective on Marketing and Distributive Justice," Liselore Crul and George Zinkhan (2008) review the basic theory of firm models that underlie the deepest assumptions that investors and top managers have about how and why corporations operate in the marketplace. In essence, resource allocation will be driven by how organizations perceive their first purposes-and, as already delineated, the fairness of resource allocation lies at the heart of DJ. Crul and Zinkhan trace the arguments that suggest stakeholder theory to be the theory of the firm most compatible with DJ; however, they also raise several powerful factors and realities that mitigate against stakeholder theory and for shareholder theory being selected by most organizations as their driving motivation.

A useful complement to the perspective of the preceding article is the article, "A Macromarketing Ethics Framework: Stakeholder Orientation and Distributive Justice" by O.C. and Linda Ferrell (2008). Here the authors formally connect the essentials of "stakeholder theory" with organizational culture and the tenets of DJ. Consistent with Crul and Zinkhan, it is clear that not all firms will seriously pursue a stakeholder orientation. But for those that accept stakeholder theory as more than PR window dressing —and a notable minority increasingly do — the artifacts of organizational culture that ought to be present to implement a justice-driven outcome for stakeholders are revealed and discussed. 
It is often observed that the devil is in the details. In the context of DJ, the details are the complex trade-offs that must be made among the various stakeholders making claims to the fruits of the marketing process. In his article, "Assessing Distributive Justice in Marketing: A Cost-Benefit Approach," Thomas Klein (2008) explores a methodology rooted in economic utilitarianism —cost/benefit analysis—-to illustrate how the sundry judgments associated with establishing a fair allocation of rewards might be structured and organized. Klein uses specific ethical issues drawn from pricing, environmental protection, and the targeting of vulnerable market segments, and provides detailed evaluations inherent in administering outcomes that will arguably pass the test for DJ.

In terms of insight into the complexities of DJ, some of the most pragmatic lessons are found in the perplexing, real-world situations where participants in the exchange process are trying to establish the very nature of what constitutes fairness. One of the more powerful contemporary movements in retail selling, both from the standpoint of advocacy groups calling for greater social justice and consumer groups demanding products that they can feel good about purchasing, is found in the fair trade movement. Basically, fair trade involves creating ethical partnerships, typically with developing market producers, which establish guarantees that these producers will receive a just reward for their market contributions and that their enterprises will have an ongoing sustainability. Fair trade coffee, tea, and cocoa are the best-known examples. In their manuscript, "Fair Trade-Just How Fair Are Exchanges?" Amina Beji-Becheur, Viginie Diaz Pedregal, and Nil Ozcaglar-Toulouse (2008) examine the concept of fair trade from the standpoint of two channels of distribution networks utilized by an organization called Lao Farmer's Cooperative. Using semi-structured interviews with channel members and "netnographic" research as background, the authors explore and analyze perceptions of trust and fairness from the perspectives of various channel partners. The thinking of various philosophers about DJ, especially Jürgen Habermas, is brought to bear on this evolving channel for agricultural products that extends to France from Southeast Asia.

In a similar vein, Emma Kambewa, Paul Ingenbleek, and Aad van Tilberg (2008), in their article, "Improving Income Positions of Primary Producers ...," use case analysis, informed by personal interviews with channel members, to dissect the fairness and justice accorded to the producers of Nile perch as the product moves from Lake Victoria in East Africa to its consumption points in the European Union. This article elaborates in a marketing context some events depicted in the award-winning movie documentary, Darwin's Nightmare (2004). The authors draw on a specific model of corporate social responsibility to examine how resource dependency and perceived legitimacy affect the response of more powerful channel members to the plight of 
weaker, sometimes helpless, upstream partner-suppliers.

Finally, in their article, "Buyer-Seller Information Asymmetry: Challenges to Distributive and Corrective Justice," Oswald Mascarenhas, Ram Kesavan, and Michael Bernacchi (2008) of the University of Detroit Mercy describe the circumstances of structured distributive injustice in the exchange process and then provide a protocol for its reduction in the market. As implied by the title, buyer-seller information asymmetry (BSIA) often lies at the center of marketplace injustices. Furthermore, corrective justice (CJ) remedies that might be found in voluntary disclosure, greater transparency, expanded socially responsible actions by the seller, and changes in public policy or regulation are thoughtfully examined. The conditions that need to be present when CJ becomes a moral imperative for marketers and society are also outlined.

\section{A Call to Action}

Taken together, these articles cover considerable research ground and, in so doing, offer systemic and managerial insight, theoretical contributions, methodological models, and new directions for extending research on various aspects of the DJ nexus. To highlight only a select few of the most obvious of implications from the articles that follow in this issue, we learn that:

- Individual firms or industry segments that are serious about the delivery of just outcomes in the marketplace must grapple with the extent to which their organization accepts and integrates the stakeholder approach to the conduct of business (Crul and Zinkhan; Ferrell and Ferrell). As we have contended here and elsewhere, the adoption of the stakeholder orientation seems essential for organizations believing that they hold broader social responsibility than merely profit maximization, especially if they want to proactively integrate ethical considerations into their marketing decision making (Laczniak and Murphy 2006).

- Arrangements to ensure greater DJ for channel partners (e.g., wholesalers, suppliers, distributors) in the exchange process will likely require high levels of trust and transparency; accurate information concerning prices, margins, and product quality; as well as some mechanism to make known distributive injustices to the greater public (Beji-Becheur, Diaz Pedregal, and Ozcaglar-Toulouse). To create a fair trade certification of some kind is only one step; it appears that verification programs are also necessary to ensure that genuine fairness is being dispensed by the parties to the fair trade agreement. Where such practices are transparent, the light of public scrutiny (and public opinion) can shine to rectify problems or exploitations that might be occurring (Kambewa, Ingelbeek 
and van Tilberg).

- Participants in the exchange process having substantial vulnerabilities, whether due to poverty, economic illiteracy, minimal financial leverage, and so forth, ought to be accorded special consideration by those parties holding greater power in the market transaction process. In the absence of a distinct sense of social responsibility on the part of the stronger channel members, other institutions that can dispense corrective justice (e.g., government regulators, courts) or other compensating support (e.g., subsidies provided by NGOs) need to be in place to attain a modicum of DJ (Mascarenhas, Kesavan, and Bernacchi). This article adds to the growing literature on vulnerable consumers (Brenkert 1998).

- Discussions of what constitutes "fairness" in market transactions, in what measure it is due to various parties, and whose conception of distributive should be used to judge particular marketing practices will continue to be a major challenge whenever questions of distributive injustice are evoked (Klein). The 2008 political debate in the United States concerning whether access to basic healthcare should be universally provided to all citizens because it ought to be a fundamental right in an affluent economy is a current example of the complexity of such deliberations.

In the end, these and related DJ considerations raise yet another round of research questions, as the conclusions of each article that follows make abundantly clear. From a big-picture standpoint, it comes down to the determination of what various stakeholders are owed due to their claims resulting from particular market transactions as well as what all participants in the global macromarketing system minimally deserve owing to their status as persons with inherent dignity. It is our hope that the set of articles contained in this special issue inspires marketing academics and public policy analysts to consider and investigate the sundry DJ issues that flow from that most enduring of inquiries about each subsystem of marketing: What conditions, rules, and outcomes constitute a fair and just system of market exchange? The answers to these questions will not be easy to determine, nor without nuance and serious trade-offs, but their exploration is the duty of marketing academics interested in the rationales underlying our current systems of market exchange.

\section{References}

Adkins, Natalie Ross, and Julie L. Ozanne. 2005. Critical consumer education: Empowering the low-literate consumer. Journal of Macromarketing 25 (December): 153-62. 
American Marketing Association updates association's code of ethics. 2004. Marketing News, September 1, 42, 40.

Baker, S. M., J. W. Gentry, and T. L. Rittenburg. 2005. Building understanding of the domain of consumer vulnerability. Journal of Macromarketing 25 (2): 128-39.

Bradford, Kevin D., Gregory T. Gundlach, and William L. Wilkie. 2005. Countermarketing in the courts: The case of marketing channels and firearms diversion. Journal of Public Policy \& Marketing 24 (Fall): 284-98.

Brenkert, G. G. 1998. Marketing to inner-city blacks: Powermaster and moral responsibility. Business Ethics Quarterly 8 (1): 1-18.

Day, George S., and David B. Montgomery. 1999. Charting new directions for marketing. Journal of Marketing 63 (Special Issue): 3-13.

Fishman, Charles. 2003. The Wal-Mart you don't know: Why low prices have high costs. Fast Company (October): 68-80.

Grow, B., and Keith Epstein. 2007. The poverty business. BusinessWeek (May 21): 56-64.

Gundlach, Gregory T., Lauren G. Block, and William L. Wilkie. 2007. Explorations of marketing in society. Mason, $\mathrm{OH}$ : Thomson.

Gundlach, Gregory T., and P. E. Murphy. 1993. Ethical and legal foundations of relational marketing exchanges. Journal of Marketing 57 (October): 35-46.

Hill, Ronald Paul, and Bahram Adranji. 1999. Global poverty and the United Nations. Journal of Public Policy \& Marketing 18 (2): 135-46.

Jackson, Kevin T. 2005. The concept of distributive justice. Encyclopedic Dictionary of Business Ethics (172-73). Oxford, UK: Blackwell.

Johnson, Herbert. 1956. Business ethics. New York: Pitman.

Kotler, Philip, Ned Roberto, and Tony Leisner. 2006. Alleviating poverty: A macro/micromarketing perspective. Journal of Macromarketing 26 (2): 233-39.

Laczniak, Gene R. 1999. Distributive justice, Catholic social teaching and the moral responsibility of marketers. Journal of Public Policy Marketing 18 (1): 125-29.

Laczniak, Gene R., and Patrick E. Murphy. 1993. Ethical marketing decisions: The higher road. Needham Heights, MA: Allyn and Bacon.

- 2006. Normative perspectives for ethical and socially responsible marketing. Journal of Macromarketing 26 (2): 154-77.

Layton, Roger A., and Sanford Grossbart. 2006. Macromarketing: Past, present, and possible future. Journal of Macromarketing, 26 (2): 193-213.

Mittelstaedt, John D., William E. Kilbourne, and Robert A. Mittelstaedt. 2006. Macromarketing as 
agorology: Macromarketing theory and the study of the agora. Journal of Macromarketing 26 (2): 131-42.

Murphy, P. E., G. R. Laczniak, N. E. Bowie, and T. A. Klein. 2005. Ethical marketing. Upper Saddle River, NJ: Pearson Prentice Hall.

Prahalad, C. K. 2005. The fortune at the bottom of the pyramid: Eradicating poverty through profits. Upper Saddle River, NJ: Wharton School Publishing.

Rangan, V. K., and Arthur McCaffrey. 2004. Globalization and the poor. In The global market: Developing a strategy to manage across borders, ed. J. Quelch and R. Deshpandi, 335-60. San Francisco: Jossey-Bass.

Rawls, John. 1971. A theory of justice. Cambridge, MA: Harvard University Press.

Santos, N., and Laczniak, G. R. 2006. Catholic social teaching and the construction of "just" markets. Paper presented at the 6th International Symposium on Catholic Social Thought and Management Education at the Pontifical University of St. Thomas, Rome, Italy, October.

Shultz, C. J. II, T. J. Burkink, B. Grbac, and N. Renko. 2005. When policies and marketing systems explode: An assessment of food marketing in the war-ravaged Balkans and implications for recovery, sustainable peace, and prosperity. Journal of Public Policy \& Marketing 24 (1): 24-37.

Urban, G. L. 2005. Customer advocacy: A new era in marketing? Journal of Public Policy \& Marketing 24 (1): 155-59.

Velasquez, M. G. 2006. Business ethics: Concepts and cases (6th ed.). Upper Saddle River, NJ: Pearson Prentice Hall.

Wilkie, William L., and Elizabeth S. Moore. 2003. Scholarly research in marketing: Exploring the "4 eras" of thought development. Journal of Public Policy \& Marketing 22 (2): 116-46.

- 2006. Macromarketing as a pillar of marketing thought. Journal of Macromarketing, 26 (2): 224-32. 


\section{Appendix}

Figure 1

The Distributive Justice Nexus

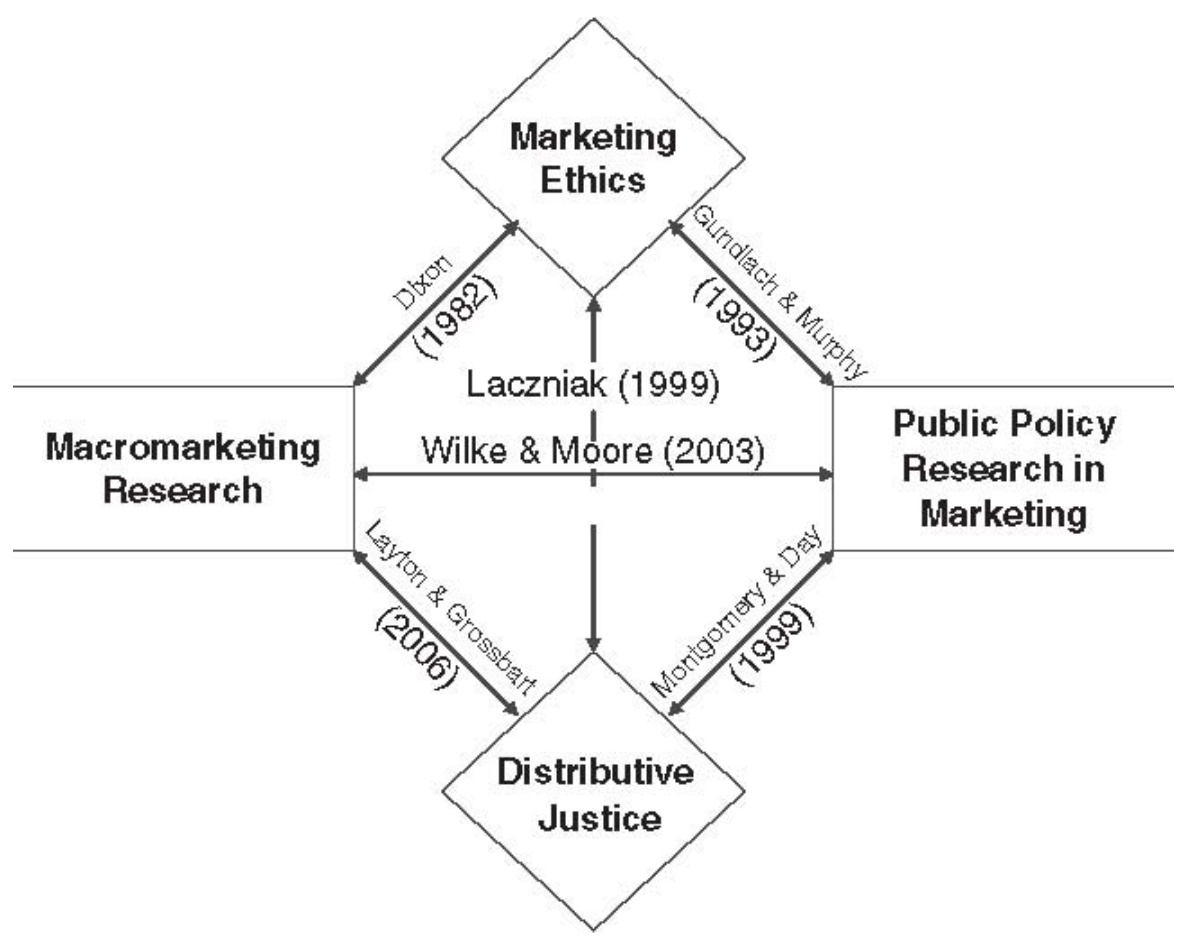

